\title{
Erratum to "Effects of the Helicobacter pylori Virulence Factor CagA and Ammonium Ion on Mucins in AGS Cells" by Zhang X, et al. (Yonsei Med J 2018;59(5):633-642.)
}

We would like to replace images of Fig. 2 and Fig. 4 with new images, for previous images cause some controversy. New images are as follows.

CK

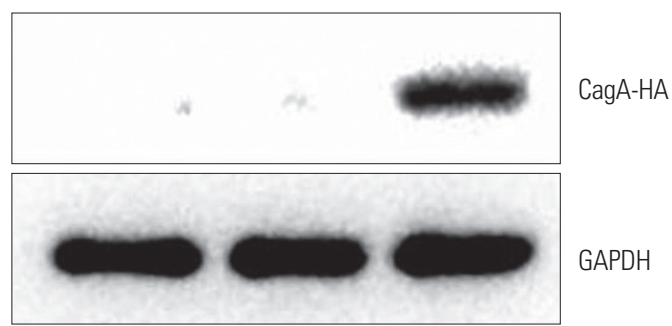

Fig. 2. CagA protein expression examined by western blotting in AGS cells. CagA protein was expressed in pCDNA3.1-CagA cells but not in CK and pCDNA3.1 cells. CK, control cells; pCDNA3.1, empty-plasmid transfected cells; pCDNA3.1-CagA, cells transfected with CagA expression vector. (c) Copyright: Yonsei University College of Medicine 2020

This is an Open Access article distributed under the terms of the Creative Commons Attribution Non-Commercial License (https://creativecommons.org/licenses/ by-nc/4.0) which permits unrestricted non-commercial use, distribution, and reproduction in any medium, provided the original work is properly cited.

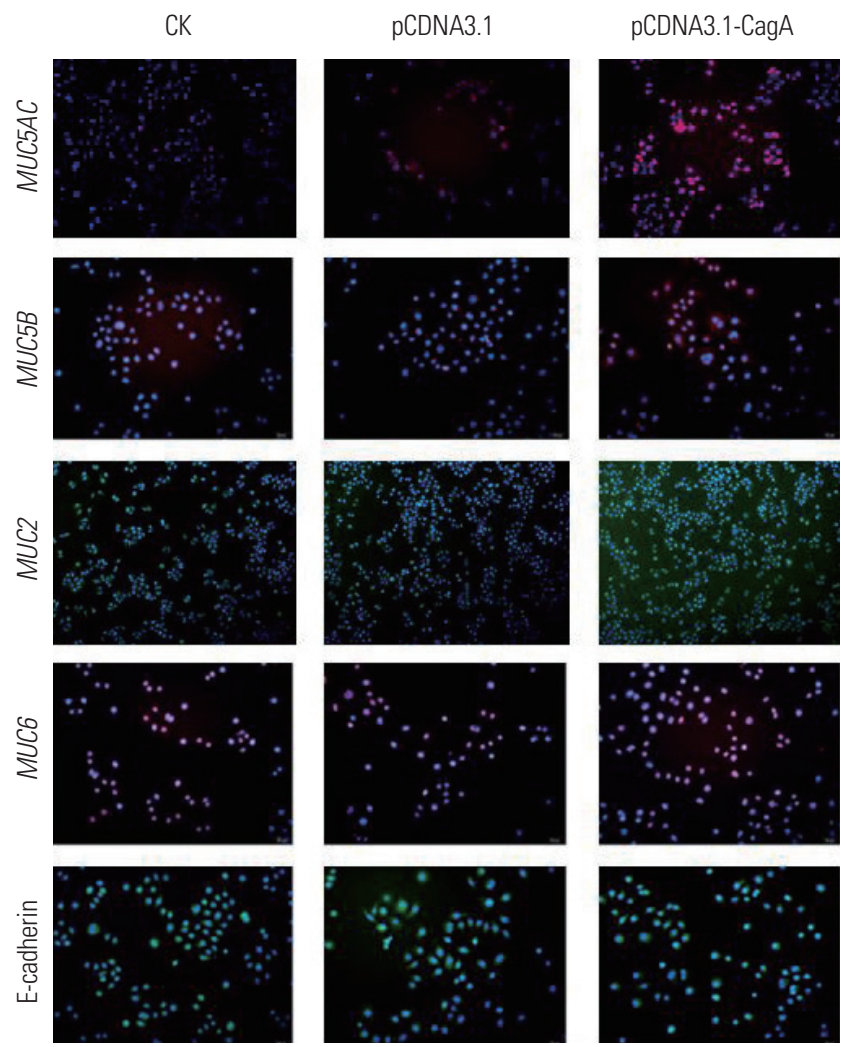

Fig. 4. Expression of mucins as detected by immunofluorescence assays ( $\times 200)$. The intensities of MUC5AC, MUC5B, and MUC2 in pCDNA3.1-Ca$\mathrm{gA}$ cells were significantly higher than those in CK and pCDNA3.1 cells. The intensity of MUC6 in pCDNA3.1-CagA cells was significantly higher than that in the pCDNA3.1 cells, but similar to that in CK cells. The intensity of $\mathrm{E}$-cadherin protein in pCDNA3.1-CagA cells was similar to that in pCDNA3.1 and CK cells. CK, control cells; pCDNA3.1, empty-plasmid transfected cells; pCDNA3.1-CagA, cells transfected with CagA expression vector. 